\title{
Taste Bud
}

National Cancer Institute

\section{Source}

National Cancer Institute. Taste Bud. NCI Thesaurus. Code C96518.

An oval body that is located in a tongue papilla and occupies the entire thickness of the epithelium. It is composed of neuroepithelial (sensory) cells, supporting cells, and basal cells. The opening at the apex of the taste bud is called taste pore. 